\title{
Breve comparação entre modos de criatividade melanésios e euro-americanos seguida de sugestões de modos ameríndios de criação ${ }^{I}$
}

\section{Camila Galan de Paula*}

Resumo: Este artigo tem por preocupação principal apresentar a proposição elaborada por James Leach sobre a existência de diferentes modos de criatividade em contextos distintos, baseando-se em sua definição alargada de criatividade. Com bases nessas proposições, buscaremos sugerir modos ameríndios de criatividade tomando como referência o artigo de Patrícia Rodrigues sobre a concepção javaé de criação e sua ênfase nas misturas entre princípios femininos e masculinos. Depois, seguindo caminhos mais tortuosos, gostaríamos de sugerir que o xamanismo amazônico como técnica de construção de conhecimento, de comunicação e de tradução é também um modo ameríndio de criatividade, conforme sugerido pelos próprios autores em que nos baseamos. Tal modo de concepção e prática da criatividade entre populações ameríndias necessita da alteridade para a realização da criação. Nesse sentido, extrapolamos a ideia de que o xamã seja o mediador/criador por excelência nas socialidades sul-americanas, e propomos que os modos de criatividade nessa região sejam pensados como inseridos no que se convencionou denominar "predação ontológica". Nosso intuito principal é o de aproximar a noção de modos de criatividade proposta por Leach do debate sobre o americanismo tropical.

Palavras-chave: modos de criatividade, xamanismo, tradução, modos de conhecimento, comparação.

Este artigo tem por preocupação principal apresentar a proposição elaborada por James Leach (2004) sobre a existência de diferentes modos de criatividade em contextos distintos, baseando-se sua definição alargada de criatividade. A

\footnotetext{
' Versão anterior deste artigo foi apresentada como trabalho final à disciplina "Redes de saberes e relações ameríndias", ministrada no segundo semestre de 2010 pela professora doutora Dominique Gallois. Agradeço às/aos pareceristas pelos comentários ao texto e pelas indicações bibliográficas, com base nas quais mudei consideravelmente a porção final do artigo. Sou grata, sobretudo, às indicações de leitura dos artigos de J. Overing e J. A. Kelly, que me auxiliaram no esforço de pensar a atividade criativa em contextos sul-ameríndios como não sendo exclusividade dos xamãs. Lamento não ter conseguido incluir na nova versão do texto todas as sugestões, que certamente permanecem como possibilidades para reflexões futuras.

${ }^{*}$ Graduanda em Ciências Sociais - USP.
} 
caracterização do autor dos modos de criatividade euro-americano e melanésio será apresentada com apoio das evidências etnográficas por ele fornecidas.

Com bases nessas proposições, buscaremos sugerir modos ameríndios de criatividade tomando como referência, inicialmente, o artigo de Patrícia Rodrigues (2007) sobre a concepção javaé de criação. Em seguida, traçando caminhos mais tortuosos, gostaríamos de sugerir que o xamanismo amazônico como técnica de construção de conhecimento (TOWNSLEY, 1993), de comunicação e de tradução (Carneiro da Cunha, 1998; Pereira, 2008) é também um modo ameríndio de criatividade, conforme sugerido pelos próprios autores que tratam do tema. Tendo como base as indicações de que o xamã não é o único mediador/tradutor, acompanhamos brevemente Aparecida Vilaça (2000) e José Antonio Kelly (2005) nas suas reflexões acerca do "tornar-se branco" entre os Wari' e Yanomami, respectivamente, para então buscarmos atingir nível maior de generalização sobre modos de criatividade sul-americanos. Retornando finalmente a considerações etnográficas, seguiremos comentando artigos de Joanna Overing (1991; 1999; 2006).

\section{Modos de Criatividade}

A preocupação de James Leach em entender maneiras alternativas à ocidental de conceber e praticar a criatividade se insere em contexto mais amplo de pesquisa. O livro em que seu capítulo está contido, Transactions and Creations (STRATHERN; HiRSCH, 2004), trata de questões de propriedade, transação e criação que são postas em evidência nos debates de propriedade intelectual e cultural. Em um mundo conectado, as ideias euro-americanas sobre criatividade e propriedade, bem como a relação entre esses termos, são confrontadas com outros modos de concepção-prática ${ }^{1}$ de criação e de autoria, e é justamente por esse motivo que o tema dos modos de criação interessa a Leach. Ele não apresenta em seu texto esses dois modos - euro-americano e melanésio - como sendo hermeticamente fechados e estáticos, mas como modos de saber-fazer que se relacionam, se cruzam e sofrem modificações mútuas.

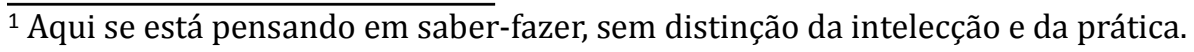


A seguir, apresentaremos os modos de criatividade euro-americano e melanésio propostos por Leach seguindo, talvez, percurso diferente do adotado pelo autor. Para este antropólogo, a criatividade opera de modos distintos em diferentes lugares e essas suas instanciações diferentes em contextos díspares têm consequências em termos de relações econômicas e sociais. Ele propõe uma definição alargada de criatividade para conseguir ir além da concepção "apropriativa" euro-americana que insiste em ligar criação intelectual à propriedade. Três são os elementos da definição geral de criatividade: (1) combinação (de coisas, de ideias ou de pessoas); (2) intenção (will); (3) inovação da forma ou resultado da combinação.

\section{Um modo euro-americano de criatividade: o modo apropriativo}

Leach aponta seis elementos que, interligados, contribuem para o que denomina modo apropriativo de criatividade. Em decorrência da concisão da formulação do autor, segue-se a transcrição:

Primeiramente, $\left[1^{\circ}\right]$ que os euro-americanos estão interessados no próprio intelecto como local de combinação eficaz. Em segundo lugar, [2으 que os resultados do intelecto devem aparecer em forma física para serem efetuados. Em terceiro lugar, [3ํㅡ que essas intervenções têm potencial de inovação, sendo contrastadas com um fundo percebido como estável. Não há agência (agency) ou intenção (will) no físico, estando incluídas aí as estruturas das sociedades humanas. Pode haver evidência de ação criativa passada, porém, em quarto lugar, [4으 uma vez efetuada em um objeto, a criatividade não pode mais estar naquele objeto, pois intenção ou agência são entendidas como residindo no sujeito. A marca ou forma do intelecto é um carimbo, não transfere aos objetos intenção ou capacidade de organização. E em quinto lugar, [5ํㅡ isso faz da criatividade intervenção humana ocasional. Ela é contingente ao "mundo" previamente estruturado; como um modo de ação, a criatividade pode ser encorajada ou suprimida. Finalmente, [6ㅜㅡ a transcendência das abstrações feitas com base nas combinações entre intelecto/intenção ressoam nas tendências euro-americanas de localizar a razão e o conhecimento na mente do indivíduo, e então reproduzir o self nessa operação (LEACH, 2004, p. 162; tradução nossa² ${ }^{2}$.

Como opção a apresentar cada uma das características acima fornecidas, seguir-se-á aqui a maneira pela qual Leach procede, apresentando o modo apropriativo de criatividade em algumas situações. De início, percebe-se que a

\footnotetext{
${ }^{2}$ Optamos por traduzir os trechos citados para maior fluidez do texto.
} 
valorização da criatividade é algo em voga na Grã-Bretanha; em ambientes empresariais e educacionais, se busca estimular a criatividade dos sujeitos, pois ela é (5ํㅜ) ocasional e contingente - nem logicamente necessária, nem logicamente impossível. Como incentivo ao surgimento dessa criatividade, os direitos de propriedade intelectual têm papel importante. Em suma, no Ocidente, a criatividade é regida pelo comércio e pela propriedade (idem, p. 156).

Outra observação importante sobre criação na Europa e na América ${ }^{3}$ é que somente se define como criatividade a combinação de inovação e de agência. Do que decorre que a inovação resultante de transformações biológicas não é criativa, pois a despeito de haver inovação, não existe na evolução ação do sujeito cognoscente. Isso vale tanto para o modelo de evolução darwiniano quanto para o modo como a concepção de novas pessoas é entendida. Homens e mulheres, ao gerarem crianças, agem instintivamente, não com a intenção de criar. Há inovação, mas não intenção, logo, para euro-americanos, não há criatividade.

A (6ํ) agência e intenção presentes no intelecto do sujeito devem ( $\left.2^{\circ}\right)$ se materializar em forma física, aí há criatividade apropriativa. Em outras palavras, esse modo de criatividade pressupõe divisão entre intelecto e materialidade, sendo apenas o primeiro locus de intenção e de agência.

É com base na combinação entre agência e inovação que "as condições corretas para se reconhecer personitude (personhood) ${ }^{4}$ entre os euro-americanos - controle sobre o mundo objetivo pelo sujeito pensante - são preenchidas" (idem, p. 161162; tradução nossa). E o que se reproduz é o self, por meio da materialidade dos objetos. Aí há espaço para noções de propriedade intelectual (realizada em objetos), uma vez que o modo apropriativo de criação acontece na reprodução da subjetividade em relação à materialidade do mundo, esta tomada como objeto de intervenção daquela. Esse é um modo ocidental de se entender a humanidade, por meio do controle da natureza. Melanésios, como se apresentará mais adiante, não operam com essa mesma divisão e não concebem sua humanidade/personitude

\footnotetext{
${ }^{3}$ A opção aqui foi por manter o uso do autor do termo "euro-americano" e não "ocidental". No entanto, usaremos "ocidental" em outros trechos, pois este artigo também trata de outros modos americanos - ameríndios - de criatividade.

${ }^{4}$ Adotamos a tradução de Marcela Coelho de Souza no artigo de Kelly (2005), indicado nas referências, para o termo personhood.
} 
(personhood) do mesmo modo; não obstante, a criação de pessoas é efeito central da criação de objetos.

\section{Um modo melanésio de criatividade: Costa Rai da Papua-Nova Guiné}

Ao apresentar um modo melanésio de criatividade, Leach é bastante específico: ele está referindo-se aos falantes de língua Nekgini, habitantes da Costa Rai na Papua-Nova Guiné, entre os quais ele desenvolveu pesquisa etnográfica. 0 autor delineia um modo de criatividade que não se baseia em apropriação. A criatividade acontece em termos de combinações, de geração de outras pessoas. Ela é necessária à personitude (personhood) melanésia, uma vez que a posse de conhecimento é qualidade indispensável à condição de humanidade e às distinções entre as diferentes aldeias.

Antes de apresentar as características gerais desse modo de criatividade e de conhecimento, seguir-se-ão resumidamente as descrições mais etnográficas de Leach. Esses habitantes da Costa Rai vivem em pequenas aldeias e a convivência em um mesmo grupo local torna as pessoas aparentadas (related). Os grupos residenciais são chamados de palem, em referência às plataformas rituais em que pagamentos aos afins são empilhados. Cada espírito da cosmologia em questão pertence a um palem e eles são herdados junto com a identidade daquele grupo residencial a que dizem respeito; ou podem ser trocados com outros palem e são então entendidos como itens de riqueza permutáveis.

Os palem são o foco de um sistema gerativo no qual se insere tal modo de criatividade. As pessoas se tornam aparentadas por meio da corresidência, e isso se dá na combinação de pessoas e de seus trabalhos na criação da nova geração.

Os filhos do palem [...] são também combinações: de trabalho, de sustento, de conhecimento e de espíritos de um lugar particular. Essas crianças são irmãs, pois elas corporificam elementos do mesmo lugar (idem, p. 163; tradução nossa).

É importante notar que "trabalho" não é entendido por melanésios do mesmo modo que por euro-americanos e a isso se retornará mais adiante.

O grupo residencial é reconhecido como entidade singular quando há produção coletiva de pagamento a outro palem, e isso ocorre quando mulheres chegam para se casar. A diferenciação de cada uma das pessoas ocorre através das 
relações que elas mantêm com o exterior do palem, com afins e parentes (kinsmen) maternos. Cada pessoa, nesse sentido, é uma combinação única de relações que mantém com o grupo residencial e com elementos exteriores a ele.

Todas essas combinações que originam pessoas, palem e espíritos, por intermédio do esforço consciente e contínuo, Leach sugere que se as denomine criatividade. Seguindo os critérios iniciais de criatividade em seu sentido amplo, há nas relações melanésias entre as pessoas: (1) combinação, (2) intenção e (3) inovação.

Esse modo de criatividade da Papua-Nova Guiné põe a ênfase na combinação de elementos criadores de pessoas. É por meio dessas combinações de relações que as pessoas existem e se diferenciam enquanto pertencentes a um grupo residencial específico, e como individualidades - embora não nos termos euroamericanos. Essas relações com o palem e para além dele não são contingentes à pessoa, mas parte constitutiva dela, "elas são esse corpo, identidade e pessoa" (idem, p. 164; tradução nossa).

Claramente contrastando o modo ocidental com o melanésio de criatividade, Leach nota que as distinções euro-americanas entre matéria/mente e reprodução biológica/criação intelectual não são operantes no segundo modo. Na Melanésia, a criação de pessoas por intermédio de relações é simultânea à criação de conhecimento. Além disso, a vida social não possui estrutura diferenciada da ação humana de se relacionar com conhecimentos.

Para explicar isso, Leach discorre brevemente sobre uma narrativa mítica pomo patuki - acerca do ato inicial de diferenciação. Um ser agiu sobre o estado primordial de indiferenciação em relação a gênero, casamento e troca. A partir do estabelecimento de diferenças, os humanos passaram a existir. Patuki não é pensado como algo intelectual e oposto ao mundo físico, pois se manifesta na paisagem e nos corpos; além de ser uma narrativa mítica, é também o próprio conhecimento. Patuki também é público, disponível a todos os humanos. Mas o que interessa a esses melanésios é o controle diferenciado que os diversos grupos têm em relação a esse conhecimento. Não sendo apenas mental, patuki é saber corporificado (embodied). Sendo público, é distribuído nos corpos das pessoas que com ele se relacionam. 
As diferenças com o modo euro-americano não param por aí. Como não há distinção entre mente/matéria, e a diferenciação entre sujeito e objeto da criação não é estanque como no Ocidente, a intenção criativa das pessoas é corporificada no que se cria através de combinações. Na Euro-América, uma vez realizadas no objeto, a intenção e a criatividade - termos inseparáveis na concepção-prática ocidental - deixam de existir, pois só podem ser atributos do sujeito. Na Melanésia, isso não ocorre assim, pois o que é criado por meio das combinações são pessoas capazes de criar outras pessoas, com base em combinações futuras.

Tomando como referência as explicações fundamentadas em solo etnográfico apresentadas aqui, é possível estabelecer alguns elementos que contribuem para o modo "combinatório" de criação/geração na Costa Rai: (1) a criatividade é condição necessária à condição humana e por isso ela é também (2) distribuída, (3) pública; as pessoas e grupos de pessoas se diferenciam por meio de (4) diferentes combinações, e essas combinações, com base em relações sociais, são manifestações de criatividade; (5) a criação mental e a reprodução são elementos de um mesmo tipo de processo criativo, uma vez que (6) não se diferencia mental e físico e que (7) o produto das combinações criativas possui agência e pode dar origem a outras pessoas; (8) o foco é na produção das pessoas por meio da produção de objetos.

Outros dois aspectos importantes são também discutidos por Leach: agência e criação mental. Em relação ao primeiro deles, o antropólogo discute a noção de trabalho. Na Costa Rai, considera-se trabalho "ações que têm efeito nos corpos e mentes de outras pessoas" (idem, p. 166; tradução nossa). 0 exemplo fornecido pelo autor é o da horticultura, que envolve a manipulação de corpos espirituais e a cooperação das esposas, além de conhecimento advindo da parentela materna. Envolve a ação de um agente sobre outros e, nesse sentido, envolve trabalho. Podese até atribuir a ação a uma única pessoa, mas o trabalho só acontece por participação e ação de outros - pessoas, espíritos e relações.

Novamente tratando da noção de pessoa na Costa Rai, Leach afirma que as pessoas são instrumentos e relações da intenção de outras. Intenção, agência e trabalho aparecem como pessoas, e pessoas são combinações desses atributos de outrem. 
Ao tratar da questão dos conhecimentos criados mentalmente, Leach se depara com o que se chamaria, usando-se categorias euro-americanas, de criação "espiritual" e "artística". É elucidador aqui o caso de um ancião que nos anos de 1970 revelou a voz de dois novos espíritos. Essas vozes são descritas como tendo aparecido na cabeça do velho, mas elas não vieram de um plano transcendente, e sim do trabalho desses seres. Espíritos são nascidos de outros espíritos, e a ênfase não é dada no caráter mental da aparição destes na mente do homem, mas no potencial de criação dessas entidades, no trabalho que despendem ao se reproduzir. A noção de autoria é, então, diferente da euro-americana, uma vez que o velho revelador da nova voz não criou nada; ele foi mero instrumento da criatividade combinatória dos espíritos.

\section{Modos de criatividade em conexão}

Conforme já enunciado anteriormente, modos de criatividade melanésios e euro-americanos não são tão distantes quanto se poderia supor. Os melanésios, como quase todas as outras populações humanas, não se encontram fora das discussões contemporâneas acerca de propriedade cultural e intelectual ou de qualquer outra discussão relevante na agenda política atual. Por isso, é importante que se registre aqui uma situação testemunhada por Leach na região em estudo, ainda que não se faça longa discussão acerca do caso.

Recentemente, estabeleceram-se na região duas empresas de processamento de cacau. Em ambas, o recrutamento de pessoal foi feito com base no grupo de residência e usou-se a retórica comunal tradicional. No entanto, disputas acerca desses empreendimentos foram frequentes e muitas delas decorreram do fato de o investidor do capital - no caso em questão, um ancião de certo grupo residencial ter se valido de dupla lógica para apropriação exclusiva do retorno do investimento, muitas vezes se furtando inclusive a pagar salários a seus trabalhadores-parentes. Leach sugere que

[...] expectativas de propriedade múltipla, baseada em princípios costumeiros do compartilhamento do lucro do produto do trabalho das pessoas é conflitante com uma leitura conveniente do capitalismo, em que ter uma ideia e torná-la realidade é suficiente para reivindicar controle exclusivo (idem, p. 156; tradução nossa). 
Esse caso parece ser um bom exemplo de como dois modos de criatividade podem estar em contato e ser modificados. Mais uma vez, é necessário ressaltar que, para Leach, esses modos de concepção-experiência da criação não são exclusivos e avessos à mudança. No próprio mundo ocidental, outros modos de criatividade coexistem com o apropriativo e estão em constante disputa, inclusive nas discussões acerca dos direitos de propriedade intelectual e de autoria.

Um modo ameríndio de criatividade: os Javaé

Patrícia de Mendonça Rodrigues apresenta em artigo intitulado "O meio como o lugar da história" (2007) o modo pelo qual os Javaé do Brasil Central concebem a criação. Apesar de dialogar com produção Melanesianista - em especial com o conceito de divíduo usado por Marilyn Strathern (idem) - ela não faz menção ao que Leach denomina "modos de criatividade". Não obstante, o que se tentará aqui é apresentar a proposição da autora em diálogo com os modos de criatividade melanésio e euro-americano tal qual expostos por Leach.

Assim como Leach faz em relação aos habitantes da Costa Rai, P. Rodrigues fundamenta sua análise em dados etnográficos específicos. No seu caso, dados javaé. No entanto, inicia seu texto apontando uma característica daquela população que é comum a outros grupos ameríndios, em especial amazônicos: a "abertura para o outro" (Lévi-Strauss apud VILAÇA, 2000), a impossibilidade de existência da sociedade "fora de uma relação imanente com a alteridade" (Viveiros de Castro apud RoDRIGUES, 2007, p. 33). A observação inicial sobre a importância da alteridade no mundo javaé se justifica, pois naquela concepção de mundo, a unidade é concebida como pedaço do outro ${ }^{5}$. Esse modo relacional de pensar está nos fundamentos da causalidade tal qual entendida pelos Javaé.

Para os Javaé, como para os melanésios da Costa Rai de Papua-Nova Guiné, a criação e a procriação não são entendidas como ações diferentes. A primeira delas não é eminentemente humana e a segunda é acidental, como os ocidentais as conceberiam. Tanto as pessoas quanto a sociedade são vistas como produto da

\footnotetext{
5 "Toda unidade, seja uma fatia de um bolo, a dança ritual da manhã, uma pessoa ou um nível cosmológico, é concebida como kyrè de algo, palavra traduzida como 'pedaço do outro', ou seja, como a parte relacional que só tem sentido em sua relação com a totalidade da qual faz parte" (RODRIGUES, 2007, p. 33).
} 
ação histórica dos homens. Seja na criação de novas pessoas ou sociedades, um princípio feminino e um princípio masculino estão envolvidos.

Os fragmentos do mito criador coletados pela antropóloga narram o início da criação como o desejo dos homens pelas mulheres. A partir de relações sexuais com as mulheres, homens encontraram a alteridade no feminino, e o fluxo de substâncias entre os corpos possibilitou o fluxo temporal e espacial da humanidade. 0 ato criador pressupõe misturas ou, usando o vocabulário de Leach, combinações entre substâncias femininas e masculinas. Essas misturas são de substâncias ou de culturas, e são elas que formam as pessoas e as sociedades, respectivamente. Apenas misturas são criativas.

Os Javaé concebem a mistura de substâncias como criação de pessoas não apenas em sentido físico ou fisiológico. Assim como combinações na Melanésia são parte precípua para a constituição da humanidade, nas terras baixas sulamericanas o "idioma da substância" e da corporalidade são categorias fundamentais para a construção da pessoa - da humanidade, portanto (SEEGER; DAMATTA; VIVEIROS DE CASTRO, 1979). Rodrigues tem por preocupação maior demonstrar como a criação das sociedades e da história é entendida e praticada pelos Javaé e não entra em detalhes maiores sobre a corporalidade.

A sociedade javaé é, em mito local, entendida como a combinação de outras duas: Tòlòra e Wèrè. Rodrigues, seguindo indicações nativas, apresenta a primeira delas como relacionada ao gênero masculino e a segunda ao feminino. Às mulheres - e a tudo o que se relaciona ao gênero feminino, como o povo Wèrè - se atribui a ambição por mudança, enquanto os homens teriam caráter mais conservador. A criação acontece pela relação social - ou física, já que a teoria nativa da procriação e a da criação histórica têm a mesma lógica causal - entre alteridades, entre o feminino e o masculino. A unidade da ação não está em um indivíduo, como no modo apropriativo de criatividade, mas justamente nessa combinação. Tanto o princípio feminino quanto o masculino são coautores da ação criativa, ambos têm intenção de criação, pois a ação conservadora dos homens é reação à ação transformadora feminina. A tentativa masculina de restaurar o status quo e de imitar o paraíso mítico, entretanto, não impede a modificação. Muito pelo 
contrário, a história no modo javaé de criatividade é entendida justamente como uma tentativa criativa de imitação.

A combinação de dois princípios opostos tem por resultado um "filho". É nesse "milagre da multiplicação de dois em três" (idem, p. 35) que reside a agência social, ou agência criativa, para nos aproximarmos mais uma vez do léxico mobilizado por Leach. A agência não reside nem nos indivíduos, como se concebe no Ocidente, nem em divíduos, como aconteceria na Melanésia, e sim na "comunidade de substância real e simbólica [...] um princípio masculino, um feminino e o produto da interação entre os dois, pois a relação que cria é indissociável da sua criação" (idem, p. 39).

Sem a pretensão de se chegar a alguma conclusão sobre o modo javaé de criatividade, o que nem seria possível fazer por intermédio da leitura de um único artigo, podemos apontar algumas características dessa concepção e prática da criação, do mesmo modo como foi feito para os melanésios e euro-americanos. Para os Javaé, a criatividade: (1) depende de mistura ou combinação entre princípios diferentes; (2) tem por locus da agência criadora e da intenção a relação entre um princípio feminino, um masculino e o resultado da criação; (3) tem a mesma lógica causal tanto para a criação de pessoas como da história social; (4) é necessária para a diferenciação dos seres e sociedades e, assim, para o estabelecimento da condição de humanidade.

\section{Sugestões de modos ameríndios de criatividade}

\section{Xamanismo e criação}

Trataremos adiante de abordagens sobre o xamanismo que enfatizam o caráter criativo dessa prática. Ao escrever sobre o xamanismo yaminahua, Townsley (1993) trata-o como um modo de construir conhecimento, dando ênfase às formas de conhecimento e não ao conteúdo sabido. Já Luis Fernando Pereira (2008), apoiando-se em Carneiro da Cunha (1998), encara o xamanismo yanomami como tradução. Ambas as abordagens destacam o aspecto criativo da atividade xamânica. Em seguida, apresentaremos separadamente o artigo de Townsley mais detalhadamente e as conclusões de Pereira. É possível extrairmos de ambos, 
contudo, alguns elementos para pensar o xamanismo como estando inserido em uma modalidade sul-ameríndia ${ }^{6}$ mais ampla de relações.

Ao apresentar o xamanismo yaminahua e sua proposição de análise, Townsley é bastante minucioso nas descrições e explicações sobre a cosmologia daquela população. Aqui destacaremos os aspectos mais importantes para sua abordagem do xamanismo como técnica de construção de conhecimento.

Elemento central para o conhecimento xamânico é o yoshi - "espírito ou essência animada" (TownSLEY, 1993, p. 452; tradução nossa). Todas as coisas do mundo são animadas pelos yoshi, e o conhecimento do xamã vem dessas entidades. Tudo o que se refere ao yoshi é extremamente ambíguo, e a "fonte da ambiguidade é que por um lado os yoshi são muitíssimo parte da natureza e dos corpos que animam e por outro eles estão bastante além" (idem, ibidem; tradução nossa) desses corpos. Justamente por se relacionar estreitamente com os yoshi, a atividade xamânica é também marcada por ambiguidades, como se mostrará mais adiante.

Outro aspecto importante a ser apontado é a constituição da pessoa yaminahua. Ela é constituída de três componentes importantes: a parte física (yora), o wëroyoshi - que é yoshi das pessoas - e o diawaka - componente não físico, possuído apenas por humanos. Townsley segue essa concepção mais de perto, e faz as seguintes observações: os Yaminahua não possuem uma noção de "mente" tal qual a ocidental, como algo interior, separado do mundo; aquilo que se poderia chamar "mental" é propriedade de entidades que não estão permanentemente ligadas a corpos físicos. Além disso, é com base nos yoshi que a semelhança entre humanos e animais se estabelece, é com base na posse universal dessa essência - usando termo de tradução adotado pelo autor - que não humanos podem se transformar em humanos, e o xamanismo faz parte desse campo de metamorfoses.

O modo de ação e de criação xamânico se insere em modo mais amplo de conhecimento, de concepções e de práticas, como as apresentadas de forma breve anteriormente. 0 saber do xamanismo, argumenta Townsley, não reside num corpus de conhecimento e nem em um tipo de pensamento, mas "em uma condição do corpo e de suas percepções" (idem, p. 456; tradução nossa). Para os Yaminahua, 6 Toda vez que usamos aqui os termos "ameríndios", "sul-ameríndios" ou mais raramente, "indígenas", estamos nos referindo às populações das terras baixas do continente sul-americano. 
os aspectos físicos do corpo são de extrema importância, e é apenas o xamã - que tem corpo e wëreyoshi mais desenvolvidos - quem consegue controlar os movimentos e percepções do wëreyoshi, "espírito" em que se assenta a percepção.

A atividade do xamã consiste prioritariamente em cantar. As músicas são os elementos mais valiosos, e é por meio delas que xamã e yoshi se comunicam. 0 uso de metáforas e analogias - caminhos tortuosos - é frequente e tem estreita relação com a ambiguidade dos yoshi. Ainda no que toca às canções xamânicas, Townsley faz referência a algo interessante para se pensar esse modo de criatividade: a noção de autoria dessas músicas. Muito embora os xamãs tenham consciência da individualidade dessas canções, eles não as veem como criações totalmente pessoais; elas não são "absolutamente criadas os possuídas por eles, mas pelos próprios yoshi, que 'mostram' ou 'dão' suas músicas” (idem, p. 458; tradução nossa) aos xamãs que as recebem como assistentes. Impossível não se lembrar do caso melanésio descrito por Leach em que a criação não se localiza na mente humana, mas no trabalho de espíritos. Apesar de a noção de trabalho não estar colocada no modo de criatividade yaminahua, também se pode argumentar que ali não há divisão mente/corpo nos mesmos termos que há para euro-americanos. Do mesmo modo, a posse do conhecimento não é humana ou, ao menos, o xamã/mediador da criação não possui aquilo que se cria por meio de sua ação. Além disso, como tudo tem yoshi, objetos criados não poderiam ser considerados inanimados, sem capacidade de agência; mais uma distância entre esse modo ameríndio e o modo euro-americano de criatividade.

Ainda em relação aos cantos dos xamã: mesmo as canções em cujo conteúdo há referências a aviões, por exemplo, não se concebe a inovação como obra mental de um homem. Justamente aí se pode entender a lógica criativa do xamanismo yaminahua: a introdução de elementos que poderiam ser considerados exógenos (avião, por exemplo) não significa alteração no modo xamânico, pois o que interessa é o modo como os saberes são construídos e não tanto o conteúdo desse conhecimento. Assim, músicas que fazem referência a elementos do mundo dos brancos apenas assinalam o caráter incompleto da cosmologia, sua necessidade permanente de construção, a "abertura para o Outro" (Lévi-Strauss apud VILAÇA, 2000). Esses elementos (como o avião, para nos atermos ao exemplo de Townsley), 
uma vez introduzidos na cosmologia yaminahua, deixam de ser brancos, foram traduzidos, seu sentido e sua rede de relações foram alterados.

Passemos às conclusões de Pereira (2008) acerca da tradução xamânica yanomami. Os xamãs são aqueles que intermedeiam as relações entre o grupo e os outros (idem; CARNEIRO DA CUNHA, 1998; TOWNSLEY, 1993), são os responsáveis por dotar algo novo de sentido tendo como referência a reunião de muitos pontos de vista, pois eles têm a capacidade de assumir outras perspectivas. 0 processo de tradução é a tentativa de construção de campos de comunicação. Mas a ênfase yanomami está no estabelecimento de diferenças, na "busca pelo entendimento de como as mesmas coisas são feitas ou de como o conhecimento é acessado e posto em prática" (PEREIRA, 2008, p. 146) de diversos modos, em contextos outros.

A tradução não elimina diferenças e tampouco é sinônimo de transposição de um significado para contexto diferente do original. 0 elemento traduzido é lido tomando como base "enredos canônicos anteriores" (idem, p. 147) e, portanto, determinado conhecimento é colocado em novas relações. Não sendo nem yanomami nem estrangeiro - até porque esses polos só se definem na relação -, o conhecimento está inscrito em rede de relações mais ampla e, ao ser traduzido, seu significado se altera justamente porque esse saber passa a ser lido tendo como referência sua nova relação com outros elementos de determinado modo de conhecimento.

A forma de acesso a saberes é o que importa para os Yanomami, assim como a circulação desse conhecimento. Ninguém possui ou cria conhecimentos - nos termos ocidentais - pois esses são obras de demiurgos, pré-existem à humanidade. Usando a definição alargada de conhecimento proposta por Leach, entretanto, a atividade do xamã-tradutor é criativa.

Ao traduzir conhecimentos de um contexto a outro, há: (1) combinação, (2) intenção e (3) inovação; pois: (1) elementos são combinados a novas relações, (2) o xamã deliberadamente traduz e (3) a tradução - longe de ser transposição de sentido - cria novos sentidos. Além disso, novos elementos podem ser introduzidos ao repertório yanomami - ou yaminahua - sem que haja modificação desse modo de criação/modo de conhecimento. Aliás, é justamente por vivenciar a alteridade que, para Pereira, o xamã pode ser tradutor. É nessa experiência de tornar-se 
"outro", com base na adoção de outros pontos de vista, que a criação ocorre, pois só há tradução se houver relação de alteridade, se houver mudança de perspectiva.

\section{Para além do xamã}

No final do artigo, Pereira deixa aberta a possibilidade de haver criaçãotradução realizada por outros agentes, como por jovens que têm relações com não indígenas e que viveram algum tempo em fazendas ou cidades. Em "A floresta de cristal: notas sobre a ontologia dos espíritos amazônicos", Viveiros de Castro (2006), tratando de tema bastante diverso, lembra, apoiando-se em diversos outros antropólogos (sobretudo A. T. Campbell) e em evidências advindas de muitas populações amazônicas, que a diferença do xamã para os outros é uma diferença de grau e não de natureza. Xamã é algo que se tem, e não que se é e, por constituir "potencial genérico do ser" (idem, p. 322), diversos agentes são potencialmente "xamanizáveis". Assim sendo, o modo de criatividade que se depreende da ação xamânica pode ocorrer em outras ações cotidianas.

Vilaça (2000), ao tratar da relação entre xamanismo e contato interétnico nos Wari', defende que "o processo de contato com os Brancos é pensado pela ótica do xamanismo" (idem, p. 57). Atualmente, esses índios usam roupas de branco e, assim, assumem perspectiva de brancos, tornam-se brancos ${ }^{7}$. Esse processo é análogo à metamorfose do xamã em animal, sobre a qual a autora escreve:

[...] o xamã se torna animal, e é como animal que adota a perspectiva dos seres humanos, wari', passando a ver os Wari' como karawa, não-humanos. Nesse sentido, o xamã propicia aos Wari', à sociedade como um todo, a experiência, indireta, de um outro ponto de vista, o ponto de vista do inimigo (idem, p. 64).

Continuando com a analogia entre vestir-se como branco e os xamãs, a antropóloga aponta: os Wari' "têm dois corpos simultâneos, que muitas vezes se confundem. São Wari' e Brancos, às vezes os dois ao mesmo tempo, como nos surtos dos xamãs" (idem, p. 69). Apesar de Vilaça não tratar do tema da tradução/criação, podemos pensar esse "vestir-se como Branco", essa adoção de perspectiva do inimigo, como forma criativa e análoga à mediação e tradução dos xamãs.

\footnotetext{
${ }^{7}$ Em seu artigo, a autora explora a importância da vestimenta como construção de corporalidade, de identidade.
} 
Também escrevendo sobre o "tornar-se branco", dessa vez entre os Yanomami, Kelly (2005) explicita o referencial teórico usado para compreender as relações yanomami com os brancos. Comentando trabalho de Viveiros de Castro (2002), refere-se à importância que a exterioridade tem para as socialidades ameríndias; e esse

[...] exterior, que envolve tipicamente as categorias de 'pessoas distantes' e 'inimigos' - mas também de pessoas não-humanas contém os recursos simbólicos para a reprodução social de pessoas e grupos, recursos frequentemente capturados por meio da inimizade simbólica e da predação canibal (KelLY, 2005, p. 206; grifo nosso).

Viveiros de Castro defende que a predação ontológica é a "modalidade prototípica da Relação nas cosmologias ameríndias" (2002, p. 164). É a partir daí que sugerimos que os modos de criatividade ameríndios se inserem nessa relação predatória: os xamãs mediadores/criadores/tradutores adotam outras perspectivas, servem como mediadores do conhecimento que recebem de outros dos yoshi, por exemplo (TOWNSLEY, 1993, p. 458) - e essa mediação/tradução poderia ser entendida como mediação canibal. Essa afirmação é bastante genérica e, ao mesmo tempo, óbvia ${ }^{8}$, por isso retornaremos uma última vez a considerações embasadas em contextos etnográficos precisos. Dessa vez, volta-se para artigos de Joanna Overing em que ela destaca a necessidade do domínio do caráter predatório das forças produtivas para que a socialidade piaroa exista.

\section{Controlando a violência predatória: os Piaroa}

Em abordagem que valoriza a socialidade interna ao grupo local ${ }^{9}$, Joanna Overing (1991; 1999; 2006) trata do "incômodo dilema ontológico" (1991, p. 24) piaroa: por um lado os "poderes produtivos [são] venenosas forças transformacionais da predação" (idem, ibidem) e por outro, a condição social somente é assegurada por intermédio do controle dessas violentas capacidades predatórias das forças produtivas. Em outras palavras, tal dilema consiste em

\footnotetext{
${ }^{8}$ Agradeço aqui aos pareceristas que, com seus comentários e sugestões de leitura, me ajudaram a desenvolver esse ponto e chegar à presente formulação.

${ }^{9}$ Essa caracterização da abordagem de J. Overing é feita por Viveiros de Castro, que chama tal ênfase teórica de "economia moral da intimidade" (2002, p. 334). A abordagem que ele mesmo, dentre outros autores utiliza, seria denominada "economia simbólica da alteridade" (p. 335).
} 
controlar o conhecimento transformacional, que pode ser muito violento, mas sem o qual não há humanidade.

Para entender isso é preciso que se compreenda que as práticas cotidianas piaroa estão inseridas na ordem cosmológica (OvERING, 1999, p. 85), e que a estética liga-se ao senso de comunidade nativo de uma socialidade igualitária. Nos tempos míticos, houve acelerado desenvolvimento tecnológico e, com o tempo, as forças produtivas foram se tornando violentas e incontroláveis para os deuses.

Todas as relações culminaram em uma relação de predador e presa, e a criação de uma comunidade pacífica tornou-se impossível. Este período criativo da história findou quando todas as forças transformacionais para produção foram lançadas deste mundo para uma nova e estável morada no espaço celestial: tais poderes são aqueles alojados na segurança das caixas de cristal dos deuses de hoje (OVERING, 1991, p. 23).

O ruwang (líder de uma comunidade), por meio de cantos e de viagens em que encontra os deuses, traz para os Piaroa esses poderes produtivos, alojados em miçangas vitais, que aloja no interior dos corpos dos indivíduos. Tais contas habilitam os indivíduos a ter a "vida dos sentidos", desejos; mas o conhecimento contido nas miçangas é chamado de "vida dos pensamentos" (idem, p. 21). A condição humana consiste justamente no controle das forças criativas por meio da combinação entre vida dos sentidos e vida dos pensamentos.

O domínio da violência predatória do conhecimento criativo advindo dos deuses é efetuado cotidianamente. 0 controle, a beleza, as artes verbais e o gênero sublime de canto xamânico (OvERING, 2006) são associados ao social. É apenas controlando o caráter degenerativo dos poderes produtivos que o mundo social se torna possível. E socialidade, para os Piaroa, é sinônimo de beleza. A estética não pode ser pensada apartadamente da moral e da política.

O controle cotidiano da violência convive com a possibilidade iminente da feiura, da predação, do domínio e da hierarquia. É com base na procriação civilizada e das artes culinárias que se domestica o conhecimento criativo. Essa arte cotidiana do preparo do alimento cozido, contudo, é ambígua. Overing (2006, p. 32) lembra o paralelismo generalizado entre comida e veneno em cosmologias amazônicas. 0 risco de não se conseguir controlar os poderes produtivos está sempre presente, e os cantos xamânicos do gênero grotesco lembram 
frequentemente os Piaroa de que a ambiguidade é real, e que a sabedoria consiste em compreender tal gênero e o perigo a que se refere.

Por fim, é importante ressaltar que a criatividade piaroa que Overing descreve é conservacionista, pois esse valor "se adequa à [...] estética de vida em comunidade e às estruturas igualitárias" (OvERING, 1991, p. 30). A criação competitiva e progressiva pertence, para os Piaroa, ao tempo mítico. Criação aliada à conservação é também algo apresentado por Rodrigues (2007) ao escrever sobre os Javaé, não custa lembrar.

\section{Considerações finais}

James Leach, quando busca alargar a noção de criatividade, o faz por perceber que a maneira pela qual o termo é entendido na Euro-América não o permitiria pensar a criação na Papua-Nova Guiné. A construção de seu argumento é baseada, ao mesmo tempo, em teorias nativas sobre o tema e em preocupação comparativa entre modos de criatividade diferentes. Buscamos estender as comparações do antropólogo às terras baixas sul-americanas e delinear sugestões acerca do que seriam e onde se articulariam os modos sul-ameríndios de criatividade/criação.

Estamos cientes da necessidade de (1) maior pesquisa bibliográfica e do (2) aprofundamento no estudo das teorias nativas para que possamos avançar nesse esforço comparativo. Assinala-se, então, o caráter restrito e modesto deste artigo, que para ser mais completo exigiria: (1) conhecimento mais amplo de contextos etnográficos distintos nas terras baixas da América do Sul ou então; (2) o aprofundamento do tema - modos de criatividade - em uma só cosmologia ameríndia.

Este exercício comparativo finda, desta feita, sem propriamente ter uma conclusão acerca de modos indígenas de criatividade. 0 que se buscou aqui, conforme se explicou anteriormente, foi trazer o debate nos termos melanesianistas para outros contextos etnográficos, afinal, "comparison is the bread and butter of anthropology" (GREGOR; TuZIN, 2001, p. 7). 


\section{Referências}

CARneiro DA Cunha, M. (1998). "Pontos de vista sobre floresta amazônica: xamanismo e tradução". Mana, Rio de Janeiro, vol. 4, n. 1, p. 7-22.

Gregor, T. A.; Tuzin, D. (2001). "Comparing Gender in Amazonia and Melanesia: a Theoretical Orientation”. In: __. (orgs.). Gender in Amazonia and Melanesia. Berkeley, University of California Press, p. 1-16.

Kelly, J. A. (2005). “Notas para uma teoria do 'virar branco'”. Mana, Rio de Janeiro, vol. 11, n. 1, p. 201-234.

LEACH, J. (2004). "Modes of creativity". In: HiRSCH, E.; StRathern, M. (orgs.). Transactions and Creations: Property Debates and the Stimulus of Melanesia. New York, Berghan Books, p. 151-175.

OvERING, J. (1991). "A estética da produção: o senso de comunidade entre os Cubeo e os Piaroa". Revista de Antropologia, São Paulo, n. 34, p. 7-33.

(1999). "Elogio do cotidiano: a confiança e a arte da vida social em uma comunidade amazônica”. Mana, Rio de Janeiro, vol. 5, n. 1, p. 81-107.

(2006)."O fétido odor da morte e os aromas da vida. Poética dos saberes e processo sensorial entre os Piaroa da Bacia do Orinoco". Revista de Antropologia, São Paulo, vol. 49, n. 1, p. 19-54.

PereirA, L. F. (2008). "Traduz quem viveu: reflexões sobre modos yanomami de tradução". Tellus, Campo Grande, ano 8, n. 15, p. 137-152.

Rodrigues, P. M. (2007). “0 meio como lugar da história”. Campos. vol. 8, n. 1, p. 3343. Disponível

em: <http://ojs.c3sl.ufpr.br/ojs2/index.php/campos/article/view/9551>. Acesso em: 2 Dez. 2010.

Seeger, A.; DaMatta, R.; Viveiros de Castro, E. (1979). "A construção da pessoa nas sociedades indígenas brasileiras"; Boletim do Museu Nacional, Rio de Janeiro, n. 32, p. 2-19.

STRATHERN, M.; HIRSCH, E. (2004). "Introduction”. In: (orgs.). Transactions and Creations: Property Debates and the Stimulus of Melanesia. New York, Berghan Books, p. 1-18.

Townsley, G. (1993). "Song Paths: The Ways and Means of Yaminahua Shamanic Knowledge". L'Homme, vol. 33, n. 126, p. 449-468. Disponível em: < www.persee.fr>. Acesso em: 18 Nov. 2010.

VILAÇA, A. (2000). "O que significa tornar-se outro? Xamanismo e contato interétnico na Amazônia”. Revista Brasileira de Ciências Sociais, São Paulo, vol. 15, n. 44, p. 56-72. Disponível em: <http://www.scielo.br/scielo.php? script=sci arttext\&pid=S0102-69092000000300003\&lng=en\&nrm=iso\&tlng=pt $>$. Acesso em: 1 Dez. 2010. 
Viveiros DE CASTRO, E. (1996). "Os pronomes cosmológicos e o perspectivismo ameríndio". Mana, Rio de Janeiro, vol. 2, n. 2, p. 115-144.

(2002). "Prólogo"; "O problema da afinidade na Amazônia"; "Imagens da natureza e da sociedade". In: _.. A inconstância da alma selvagem e outros ensaios de antropologia. São Paulo, Cosac Naify, p. 11-23; 89-180; 319-344.

(2006). "A floresta de cristal: notas sobre a ontologia dos espíritos amazônicos". Cadernos de Campo, São Paulo, n. 14/15, p. 319-338.

Recebido em janeiro/2011

Aprovado em julho/2011 